Tetiana Anoshkova

\section{Lecturer}

National Technical University of Ukraine

"Igor Sikorsky Kyiv Polytechnic Institute"

Kyiv, Ukraine

ORCID ID 0000-0002-9560-942X

taniaanoshkova@gmail.com

\title{
THE ROLE OF LIBERAL ARTS IN EDUCATING FUTURE ENGINEERS
}

\begin{abstract}
The article studies the possibility of liberal arts integration into the undergraduate curriculum of Ukrainian technical universities and colleges in general and Igor Sikorsky Kyiv Polytechnic Institute in particular. Having studied the experience of different countries, it was found out that the US colleges are considered the best example of liberal arts education. In the following research work the author studies the liberal arts programmes of the eight private universities of the United States, which remains the members of the Ivy League, and analyses their education principles, core curriculum, and skills they develop. Highlighting the two approaches to curriculum arrangements, which are core-type and distribution-type systems, the author studies their distinctive features. Having analysed the programmes offered by the universities under consideration it was found out that the main areas of knowledge include arts and humanities, natural and social sciences and within these areas the core curriculum is compiled. Based on the achieved information there is presented a list of global competencies, each university or college is aimed at. The main global competencies which are typical for all of the studied universities and colleges include critical thinking, cultural awareness, intercultural collaboration, and problem-solving. Having studied the development strategy of the National Technical University of Ukraine "Igor Sikorsky Kyiv Polytechnic Institute" (hereinafter officially abbreviated name - Igor Sikorsky KPI) it is determined that this strategy supports the aims which lay the foundation to the modern liberal arts colleges. The author states that it is impossible to educate the well-rounded, globally-oriented engineering specialists in the $21^{\text {st }}$ century without developing their global competencies and broadening the areas of knowledge acquired.
\end{abstract}

Keywords: core curriculum; critical thinking; engineering students; global competences; liberal arts education; intercultural communication; undergraduate studies.

\section{INTRODUCTION}

Problem statement. Global trends of the $21^{\text {st }}$ century are showing us that technologies determine the future; they set up the trends and control the economies. In the rapidly changing world soon there will be no place for the traditional professions connected with the repetitive and routine work as people will be substituted with machines. Even such tasks as X-ray results interpretations no longer require human intervention and are already successfully performed by computers. Such tendencies explain the change in job requirements with soft skills dominating at the labour market. Today more and more colleges in Europe and Asia shift their paradigm from teaching professional skills towards global competences and teach their students to face global challenges and solve global problems.

In Ukraine there is a gap in education where there are vocational schools that offer the undergraduate courses with rather "professional curriculum" as well as higher educational institutions that train bachelors and masters in engineering, computer science, and law. However, with the lack of knowledge in humanities and social sciences, our graduates lag behind the specialists with European or American education which slows down the development of our economy.

Theoretical background. As stated in the development strategy of Igor Sikorsky KPI for 2020-2025 "...the success in the creation of the new can be reached only by a person who has extensive training - not only in the field of the 8 sciences, but also in the humanities, literature, music, fine arts, in the human values sphere, which develop the aesthetic perception of engineering and sciences" (p. 7). This means that modern challenges of a global world require educated and 
successful engineers of the $21^{\text {st }}$ century which becomes possible due to general education. The essence of such education is not what you study, but the result: gaining the ability to think critically, understanding global issues, and solving them with the commitment to sustainability.

The mission of Harvard College states that before students can help change the world, they need to understand it (Liberal Arts \& Sciences). As Fedorenko (2014) notes, Liberal Arts are edifying elements of culture which provide great intellectual importance and contribute to moral and cultural (self) development of students. It "yields a comprehension of general principles with a thorough grounding of the world perception" (p. 82). Thus, such education, which teaches students how to think critically and argue effectively, preparing them for positions of leadership and a life of service to the nation and all of the humanity, is a liberal arts education.

Sklad, Friedman, Park and Oomen (2015) in their research work "Going Glocal" point out that in contrast to the United States, where liberal arts colleges have existed since the $17^{\text {th }}$ century; they are relatively new in Europe, particularly in the Netherlands (p. 326). If we talk about Asia, there have been attempts to adapt the concepts of the US liberal education while maintaining the intellectual and cultural concepts of East Asia since the $17^{\text {th }}$ century (Jung, Nishimura, \& Sasao, 2018, p. 126). The first Women's College of the Liberal Arts in Japan was founded as early in Kyoto as 1876 (Lewis, 2018, p. 21), while in Singapore the idea of the first private liberal arts college appeared only in 2007 (Lewis, 2018, p.17).

However, it is the United States that is considered the motherland of a liberal arts education as we know it today (Sklad, Friedman, Park \& Oomen 2015, p. 326; Fedorenko, 2015). Thanks to the foundation of such universities as Harvard, Yale, Princeton, and other members of the Ivy League a liberal arts education has still been perceived as "an expansive intellectual grounding in all kinds of humanistic inquiry" (What Does Liberal Arts Mean?).

In 1850 Brown's fourth president Francis Wayland (Explore Brown University) claimed that a student should be able to "study what he chose, all that he chose, and nothing but what he chose". Years later this idea was used as the basis for a new approach at Brown: the open curriculum.

With the "professional curriculum" prevailing at education institutions nowadays, modern Presidents of Harvard and Princeton highly value a liberal arts education calling it "a vital foundation for both individual flourishing and the well-being of our society" (Princeton University Admission, 2013).

Thus, the purpose of the article is to analyse the structure of the undergraduate curricula of the most prestigious liberal arts colleges of the United States which successfully combined professional and general education in order to identify their contribution to the development of global competences and to use it as an example for the improvement of the professional education in Ukrainian universities and colleges.

\section{METHODS}

While conducting the research there were analysed the existing research works connected with the development of liberal arts education. It was determined that the most significant contribution to the development of a liberal arts education was made by the United States educational institutions. Having determined the eight most prestigious colleges and universities according to the ranking presented by Caffee (2019) which combine liberal arts principles for undergraduate students with graduate and research programmes, we used a qualitative research method to analyse the data. After collecting all the existing information connected with a liberal arts approach to undergraduate education, a comparative table was created.

There were determined the types of curricula, the main study areas and skill areas as well as the key global competencies which are to be developed in the course of the professional engineering training. The results of the data analysis were used to suggest improvements in the undergraduate curriculum for the engineering students of Igor Sikorsky KPI which correspond to the new development strategy of the university. 


\section{RESULTS AND DISCUSSIONS}

\subsection{The principles of a liberal arts education}

A liberal education originates from ancient Greece and its philosophers, such as Seneca, Plato, and Aristotle who cultivated freedom of thought, and responsible citizens with a social conscience (Lewis, 2018; Sklad, Friedman, Park \& Oomen, 2016).

Since the Latin word "arts" means both the arts and the sciences, the first Western universities distinguished seven study areas, three of which belonged to languages (grammar, rhetoric and logic) and four others based on numbers (geometry, arithmetic, music, and astronomy) (Lewis, 2018, p. 18). With the historical development, this structure has changed but the basic concept has been the same.

Most liberal arts programmes adhere to the core curriculum which is comprised of several areas of knowledge. The core-type system offers a set of courses that all students take together (Bailyn, 2020, p. 165). This type of programme is aimed at sharing experience, discussion sessions, studying, and cooperating in a multicultural environment. Most colleges with core curriculum offer the number of disciplines in the following areas of knowledge: arts and humanities, foreign languages, natural and social sciences (Appendix A). The courses commonly included in the humanities are history and historical analysis, literary studies and writing, ethical thought and moral values, philosophy and religious studies. Theatre, dance, musical theory and musical performance belong to performance arts. For a social sciences course students can choose sociology, anthropology, economics, political science, and psychology. Courses generally not considered liberal arts include those in athletics, business (including accounting, management and finance), education, and engineering (Liberal Studies). Three core skills areas that are outlined in all undergraduate programs include critical thinking, writing, and analytical or quantitative reasoning (Appendix A). As it is stated in the Yale programme: "gaining the ability to think critically and independently and to write, reason, and communicate clearly [is] the foundation for all professions" (A Liberal Arts Education).

Another approach is a system of distribution requirements that is used by such universities as Yale, Harvard and Brown, where students do not have a pre-determined set of disciplines but can choose freely from the list of existing courses in humanities, social and natural science throughout their undergraduate years. It is stated that the "depth is covered in [their] majors" (A Liberal Arts Education) while the "breadth" part encourages students to expand on their interests and explore new areas of knowledge (Bailyn, 2020, p. 165). It focuses mainly on independent creative thought. The faculties are allowed to choose what they teach and how they teach, and the faculty members acquire the role of guides and mentors. However, a distribution system has some disadvantages since a lot of students tend to stay in their comfort zone and choose the already familiar subjects (Bailyn, 2020, p. 166).

Thus, each of the universities and colleges presented in Appendix A offers a range of courses in three main areas of knowledge. At the same time, several universities give autonomy to the faculties and allow their students to choose any course they like within the suggested areas of study.

\subsection{Educating globally competent engineers}

According to the development strategy of Igor Sikorsky Kyiv Polytechnic Institute for 2020 2025 , the university is going to respond to the global challenges in the conditions of the $4^{\text {th }}$ industrial revolution by making changes in structure, content and quality of specialist training (p. 9). The university members are going to support partnerships with the high-tech labour market taking into account global trends in the scientific and technological development, and strengthen international cooperation. This all means that global competencies will play a major role in the upbringing of future specialists.

The idea of a liberal arts education is closely connected with global education. The programme of liberal studies for engineering students at Cornell University states that "global and diverse societies require that engineers have an awareness of historical patterns, an appreciation for different cultures, professional ethics, the ability to work in multi-faceted groups, and superior 


\section{communication skills" (Liberal Studies).}

There is no clear definition of what global competences are. Many colleges, universities and international organizations have developed their own lists of skills that are needed to work effectively within a global environment (Schejbal \& Irvine, 2009, p. 125-126). However, global competencies consist of knowledge (the knowledge of history, foreign languages and world cultures; understanding of such global issues as migration processes, poverty, and climate changes), skills (critical and analytical thinking, communication skills, cross-cultural teamwork and leadership), values and attitudes (self-awareness, respect for cultural otherness, openness towards people from other countries and humanism) needed to function effectively within an international environment (Anoshkova, 2015).

The sets of global competencies that have been determined after the analysis of undergraduate programmes of the Ivy League members are very similar (Appendix A). Each liberal arts college is focused on the development of critical and comparative thinking. All the programmes are oriented on solving global problems, learning how to work in a multicultural environment, face the challenges of the modern world, and stay positive about life. Despite the entire global context, students are taught to remember their own culture and identity, to understand and appreciate their own historical heritage.

To sum up, liberal arts and global education are interconnected, so knowledge, skills and attitudes which form the basis of a liberal arts education foster global competencies, necessary to educate globally oriented and successful professionals.

\section{CONCLUSIONS AND SCOPE FOR FURTHER RESEARCH}

To conclude, we can confirm that the goals of liberal arts education meet the requirements of the modern world. A liberal arts programme is the combination of depth and breadth of study which allows educating well-rounded specialists in any engineering branch who will readily face the challenges of the $4^{\text {th }}$ industrial revolution. Thus, it can be stated that a liberal arts education corresponds to the goals set in the 2020-2025 development strategy of Igor Sikorsky KPI. We can create our own liberal arts environment choosing a core-type or a distribution-type system with the disciples within such areas of study as arts and humanities, foreign languages, natural and social sciences. Great attention must be kept to the development of such skills as writing, quantitative reasoning, critical and analytical thinking which overlap with global competences to form the basis of a liberal arts education.

The theoretical study shows how the wide range of arts and sciences can be integrated into the curriculum along with the specialised education in a major to create the academic background suitable for the $21^{\text {st }}$-century citizens.

However, the experience of other countries is still to be studied with a detailed curriculum to be designed in order to satisfy the needs of modern graduates and faculty members. The results of the practical application of a liberal arts framework in the Ukrainian technical colleges and universities and general, and Igor Sikorsky KPI, in particular, is the next step of further research.

\section{REFERENCES}

A Liberal Arts Education. (n.d.). Retrieved June 1, 2020, from https://admissions.yale.edu/liberal-arts-education

Anoshkova, T. A. (2015). Implementation of Global Competency In Higher Education. Advanced Education, 3, 4-8. doi: $10.20535 / 2410-8286.43743$

Bailyn, C. (2020). Diversifying the Liberal Arts Curriculum in an Asian Context. Diversity and Inclusion in Global Higher Education, 163-181. DOI: 10.1007/978-981-15-1628-3_6

Caffee, A. (2019). 2020 List of Ivy League Schools, Ranked and Reviewed. Retrieved June 1, 2020, from https://www.niche.com/blog/list-of-ivy-league-schools-ranked-and-reviewed/

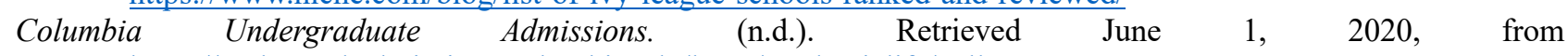
https://undergrad.admissions.columbia.edu/learn/academiclife/college

Dartmouth at a Glance. (n.d.). Retrieved June 1, 2020, from https://home.dartmouth.edu/dartmouth-glance

Explore Brown University. (n.d.). Retrieved June 1, 2020, from https://www.brown.edu/sheridan/liberal-learning

Fedorenko, S. (2014). Liberal Arts Education in the Instructional Setting of Higher School. European Science Review: 
International Scientific Journal, 9-10, 82-83.

Fedorenko, S. (2015). Liberal arts as broad integrative learning in the USA undergraduate education. European Humanities Studies: State and Society, 2, 56-64.

Jung, I., Nishimura, M., \& Sasao, T. (2018). Liberal Arts Education and Colleges in East Asia Possibilities and Challenges in the Global Age. Puchong, Selangor D.E.: Springer Singapore.

Lewis, P. (2018). Globalizing the Liberal Arts: Twenty-First-Century Education. Higher Education in the Era of the Fourth Industrial Revolution, 15-38. DOI: 10.1007/978-981-13-0194-0_2

Liberal Arts \& Sciences. (n.d.). Retrieved June 1, 2020, from https://college.harvard.edu/academics/liberal-arts-sciences

Liberal Studies. (n.d.). Retrieved June 1, 2020, from https://www.engineering.cornell.edu/students/undergraduatestudents/advising/liberal-studies-0

Policies Governing Foundational Approaches. (n.d.). Retrieved June 1, 2020, from https://www.college.upenn.edu/foundational-policy

Schejbal, D., \& Irvine, G. (2009). Global Competencies, Liberal Studies, and the Needs of Employers. Continuing Higher Education Review, 73, 125-142. Retrieved from https://files.eric.ed.gov/fulltext/EJ903457.pdf

Sklad, M., Friedman, J., Park, E., \& Oomen, B. (2015). Going Glocal: a qualitative and quantitative analysis of global citizenship education at a Dutch liberal arts and sciences college. Higher Education, 72(3), 323-340. doi: 10.1007/s10734-015-9959-6

The strategy of development of the National Technical University of Ukraine "Igor Sikorsky Kyiv Polytechnic Institute" 2020-2025. (n.d.). Retrieved from https://data.kpi.ua/sites/default/files/files/2020-2025-strategy en.pdf

Princeton University Admission. (n.d.). Retrieved June 1, 2020, from https://admission.princeton.edu/academics/whatdoes-liberal-arts-mean

Appendix A. The Ivy League Liberal Arts Colleges

\begin{tabular}{|c|c|c|c|}
\hline $\begin{array}{l}\text { Higher educational } \\
\text { institution }\end{array}$ & $\begin{array}{l}\text { Type of curriculum } \\
\text { for general education }\end{array}$ & $\begin{array}{c}\text { Areas of Knowledge / } \\
\text { Skill areas }\end{array}$ & Global Competences \\
\hline Princeton University & Core-type curriculum & $\begin{array}{l}\text { Epistemology and cognition, ethical } \\
\text { thought and moral values, historical } \\
\text { analysis, literature and the arts, } \\
\text { laboratory science and technology, } \\
\text { and social analysis / writing, } \\
\text { quantitative reasoning, critical and } \\
\text { analytical thinking }\end{array}$ & $\begin{array}{l}\text { - Critical and comparative } \\
\text { thinking; } \\
\text { - social and cultural awareness; } \\
\text { - problem-solving on the global } \\
\text { level; } \\
\text { - positive outlook about the } \\
\text { future and proactive; } \\
\text { engagement in the world; } \\
\text { - openness to learning and a } \\
\text { positive orientation to new } \\
\text { opportunities, ideas, and ways } \\
\text { of thinking. }\end{array}$ \\
\hline Yale University & $\begin{array}{l}\text { Distribution-type } \\
\text { curriculum }\end{array}$ & $\begin{array}{l}\text { Humanities and arts, sciences, and } \\
\text { social sciences / writing, quantitative } \\
\text { reasoning, and foreign language. }\end{array}$ & $\begin{array}{l}\text { - Critical and comparative } \\
\text { thinking; } \\
\text { - } \quad \text { self-awareness and self- } \\
\text { esteem about one's } \\
\text { own identity and culture; } \\
\text { - openness to learning and a } \\
\text { positive orientation to new } \\
\text { opportunities, ideas, and ways } \\
\text { of thinking. }\end{array}$ \\
\hline Harvard University & $\begin{array}{l}\text { Distribution-type } \\
\text { curriculum }\end{array}$ & $\begin{array}{l}\text { Arts and humanities, sciences and } \\
\text { social sciences / writing, analytical } \\
\text { reasoning, critical thinking. }\end{array}$ & 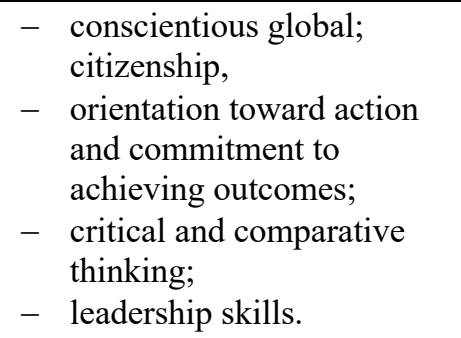 \\
\hline
\end{tabular}




\begin{tabular}{|c|c|c|c|}
\hline Brown University & $\begin{array}{l}\text { Distribution-type } \\
\text { curriculum }\end{array}$ & $\begin{array}{l}\text { Humanities, social sciences, life } \\
\text { sciences, and physical sciences / } \\
\text { speaking and writing (in native and } \\
\text { foreign languages). }\end{array}$ & 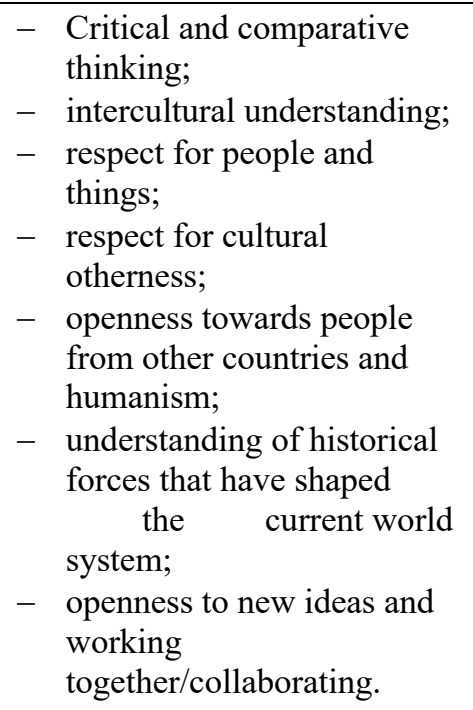 \\
\hline Dartmouth College & Core-type curriculum & $\begin{array}{l}\text { Arts and humanities, sciences, } \\
\text { interdisciplinary programs and social } \\
\text { sciences / visual analysis, logical } \\
\text { reasoning, critical reading and } \\
\text { writing, and public speaking. }\end{array}$ & $\begin{array}{l}\text { - Critical and comparative } \\
\text { thinking; } \\
\text { - an openness to new ideas and } \\
\text { working } \\
\text { together/collaborating; } \\
\text { - strong interest in learning at } \\
\text { multiple levels and in seeking } \\
\text { opportunities for continuous } \\
\text { learning and professional } \\
\text { growth; } \\
\text { - knowledge of effective } \\
\text { communication, including } \\
\text { knowledge of a foreign } \\
\text { language, intercultural } \\
\text { communication concepts, and } \\
\text { international business } \\
\text { etiquette. }\end{array}$ \\
\hline Columbia College & Core-type curriculum & $\begin{array}{l}\text { Literature, art and music humanities, } \\
\text { contemporary civilization, university } \\
\text { writing, frontiers of science / critical } \\
\text { thinking, analysis, argument, } \\
\text { quantitative reasoning, logical } \\
\text { inference and creative thinking.. }\end{array}$ & $\begin{array}{l}\text { - Critical and comparative } \\
\text { thinking; } \\
\text { - awareness of the complexity } \\
\text { and interdependence of world } \\
\text { events and issues; } \\
\text { - empathy or the ability to take } \\
\text { multiple perspectives; } \\
\text { - ability and desire to work } \\
\text { constructively with people of } \\
\text { all backgrounds and } \\
\text { orientations. }\end{array}$ \\
\hline Cornell University & Core-type curriculum & $\begin{array}{l}\text { Humanities, arts, foreign languages, } \\
\text { interdisciplinary courses and social } \\
\text { sciences / oral and written } \\
\text { communication, information literacy, } \\
\text { data analysis and problem-solving. }\end{array}$ & $\begin{array}{l}\text { - Critical and comparative } \\
\text { thinking; } \\
\text { - historical patterns awareness; } \\
\text { - openness to new ideas and } \\
\text { working } \\
\text { together/collaborating, } \\
\text { cooperative skills, } \\
\text { intercultural awareness, } \\
\text { - ability to challenge injustice } \\
\text { and inequities } \\
\text { - ability to recognise } \\
\text { assumptions and implications. }\end{array}$ \\
\hline
\end{tabular}




\begin{tabular}{|c|c|c|c|}
\hline $\begin{array}{ll}\text { University } & \text { of } \\
\text { Pennsylvania } & \end{array}$ & Core-type curriculum & $\begin{array}{l}\text { Society, history and tradition, arts and } \\
\text { letters, humanities and social } \\
\text { sciences, living world, physical } \\
\text { world, natural sciences and } \\
\text { mathematics / writing, quantitative } \\
\text { data analysis, formal reasoning and } \\
\text { analysis, cross-cultural analysis, } \\
\text { cultural diversity in the US and } \\
\text { foreign language requirements. }\end{array}$ & $\begin{array}{l}\text { - Critical and comparative } \\
\text { thinking; } \\
\text { - Working towards sustainable } \\
\text { development; } \\
\text { - understanding of the diversity } \\
\text { found in the world in terms of } \\
\text { values, beliefs, ideas, and } \\
\text { worldviews; } \\
\text { - openness to learning and a } \\
\text { positive orientation to new } \\
\text { opportunities, ideas, and ways } \\
\text { of thinking. }\end{array}$ \\
\hline
\end{tabular}

Тетяна Аношкова. Роль гуманітарної освіти у підготовці майбутніх інженерів. Стаття присвячена вивченню гуманітарної освіти та можливості впровадження елементів гуманітарного навчання у навчальну програму закладів повної вищої, базової вищої та професійно-технічної освіти загалом та Національного технічного університету України «Київський політехнічний інститут імені Ігоря Сікорського» (КПІ ім. Ігоря Сікорського) зокрема. Встановлено, що американські коледжі слугують найкращим прикладом запровадження загальної гуманітарної підготовки для студентів різних спеціальностей. Для проведення дослідження авторка вивчила програми підготовки бакалаврів восьми приватних університетів Америки, які входять до Ліги Плюща. У результаті було проаналізувано освітні принципи, ключові аспекти навчальних програм та навички, які розвиваються в процесі навчання 3 залученням гуманітарної освіти, зокрема навчання іноземної мови та академічного письма. За основу компонування навчального плану для студентів було взято дві навчальні програми: навчальна програма 3 набором базових курсів, які є обов'язковими для всіх студентів, та програма, що пропонувала курси за вибором в межах трьох областей знань (гуманітарні, природничі та соціальні науки). Беручи за основу отриману інформацію, укладено перелік глобальних компетентностей, які кожен заклад вищої освіти має розвивати у процесі підготовки спеціалістів. Ключові глобальні компетентності, які представлені в аналізованих програмах усіх університетів, що були розглянуті, включають: критичне мислення, культурну самоідентифікацію, міжкультурну співпрацю та навички вирішення глобальних проблем. Опрацювавши стратегію розвитку КПІ ім. Ігоря Сікорського, було встановлено, що основні цілі, зазначені в ній, можуть стати базою для впровадження гуманітарної освіти в Україні. Авторка стверджує, що саме розвиток глобальних компетентностей та розширення області знань студентів технічних спеціальностей $\epsilon$ необхідними для підготовки всебічно розвинутих та конкурентоспроможних фахівців 21-го століття. Запропоновано використати результати цього наукового дослідження для створення навчальної програми, що буде задовольняти глобальні світові потреби.

Ключові слова: базова вища освіта; глобальні компетентності; гуманітарна освіта; міжкультурна комунікація; навчальна програма; критичне мислення; студенти інженерних спеціальностей. 